\title{
Strain differences in free operant leverpress levels in the rat
}

\author{
GORDON M. HARRINGTON \\ University of Northern Iowa, Cedar Falls, Iowa 50613
}

\begin{abstract}
Unconditioned leverpress operant levels were obtained in a standard apparatus for 485 rats from 12 inbred strains: ACI, A990, A35322, F344, INR, IR, MNR/Har, MNRA, MR/Har, TS1, TS3, WAG. The results provide parametric data for methodological use and add to the standardization of these strains as behaviorally defined lines. Free operant rate did not appear to be genetically related to other common measures of spontaneous activity.
\end{abstract}

Since its introduction, the Skinner $(1933,1938)$ box has become the premier apparatus of psychology contributing to a significant change in methodology and in conceptual analysis. Over a parallel time period, study of the inheritance of behavior evolved into a distinct specialty first labeled behavior genetics 20 years ago by Fuller and Thompson (1960), a title to be applied to its specialty journal a decade later. In view of the extent to which the operant conditioning paradigm has come to dominate animal studies, it is rather remarkable that studies relating genetic variation and operant behavior in a Skinner box are so very few in number. Much of the work dates back 40 years to two studies of extinction (Heron \& Skinner, 1939, 1940) and one of spontaneous recovery (Estes, 1942) in two strains of rats differing in maze performance. Somewhat more recently, strains differing in coat color have been used in examining effects of light contingent upon barpress (Lockard, 1962), while strains differing in reactivity have been used in a study of positive reinforcement with electric shock (Harrington \& Kohler, 1966).

The present study initiates systematic examination of strain differences in operant behavior by starting at the starting point of determining the unconditioned operant rate for leverpressing in a standard Skinner box. The purpose was to provide standardization data on this variable for those 12 genetically defined lines of rats having the highest citation frequency in the behavioral literature. It is one of a number of parametric studies (Harrington, 1971a, 1971b, 1979a, 1979b, 1979c, 1979d, 1979e, 1979f, 1979g, 1979h; Harrington \& Hellwig, 1979a, 1979b) contributing to such behavioral standardization paralleling similar methodological concerns in precise specification of animal models to be found in other areas of research (International Committee on Laboratory Animals, 1971).

\section{METHOD}

\section{Subjects}

Subjects were 485 rats, aged 75-89 days, with a minimum of 20 animals of each sex within each of the following 12 inbred strains: ACI/Har, A990/Har, A35322/Har, F344/DuHar, INR, IR, MNR/Har, MNRA (formerly MNR-a/Har), MR/Har, TS1, TS3, WAG/Har. All lines are designated by the standard nomenclature for this species and are described in the fourth international listing (Festing \& Staats, 1973). Animals were bred and maintained at $25.5^{\circ} \mathrm{C} \pm 1.1^{\circ} \mathrm{C}$ and $40 \% \pm 5 \%$ relative humidity. Breeders and pups were housed under natural light cycle. Pups were handled for $1 \mathrm{~min}$ on alternate days from age 14 to 45 days. At 45 days, they were transferred to individual cages with 24-h light cycle. More detailed descriptions are available elsewhere (Harrington, 1968).

\section{Apparatus and Procedure}

Animals were maintained on ad-lib food and water. Daily, for 5 days, animals were placed in a Lehigh Valley Electronics Model 1416 operant conditioning unit. Leverpresses were observed each day for a period of $1,000 \mathrm{sec}$ and recorded and filed with a data acquisition system.

\section{RESULTS AND DISCUSSION}

The total number of leverpresses for 5 days at $1,000 \mathrm{sec} /$ day together with standard deviations are shown for each strain and each sex within each strain in Table 1.

Clearly, INR shows markedly higher free operant rates than does any other strain. Where such a characteristic was useful in an experimental design, these would be the animals of preference. Quite low operant rates characterize the IR, MNR/Har, and TS1 lines. The remaining eight lines appear to be intermediate between these extremes.

Since operant level could be considered an index of activity, it is relevant to compare these rates with some common activity measures for the same strains (Harrington, 1971b, 1972, 1979b). For males and for females, respectively, the rank-difference correlation 
Table 1

Unconditioned Leverpress Operant Rate of 12 Inbred Strains of Rats

\begin{tabular}{|c|c|c|c|c|}
\hline \multirow[b]{3}{*}{ Strain } & \multicolumn{4}{|c|}{ Operant Rate* } \\
\hline & \multicolumn{2}{|c|}{ Males } & \multicolumn{2}{|c|}{ Females } \\
\hline & Mean & SD & Mean & SD \\
\hline $\mathrm{ACI} / \mathrm{Har}$ & 7.1 & 5.6 & 13.0 & 10.9 \\
\hline A990/Har & 11.4 & 12.6 & 11.2 & 12.8 \\
\hline A $35322 / \mathrm{Har}$ & 13.7 & 7.6 & 17.4 & 10.7 \\
\hline F 344/DuHar & 12.3 & 11.6 & 10.2 & 8.8 \\
\hline INR & 32.1 & 29.1 & 39.6 & 38.2 \\
\hline IR & 2.3 & 2.5 & 3.4 & 5.1 \\
\hline MNR/Har & 3.4 & 4.4 & 2.0 & 3.9 \\
\hline MNRA & 11.3 & 10.5 & 11.0 & 12.4 \\
\hline MR/Har & 10.9 & 16.0 & 5.8 & 4.7 \\
\hline TS 1 & 3.2 & 3.9 & 2.1 & 1.9 \\
\hline TS3 & 15.7 & 13.5 & 16.5 & 13.6 \\
\hline WAG/Har & 10.9 & 8.0 & 5.1 & 4.5 \\
\hline
\end{tabular}

Note $-N \geqslant 20$ for each sex within each strain.

*Leverpresses per five 1,000-sec sessions.

of strain means was .54 and .30 with center crossings in a stabilimeter, .31 and .36 with ambulation in an open field, and .21 and -.21 with activity cage revolutions. None of these are significant, suggesting that in terms of genetic influences, operant rate is a variable based on somewhat different factors than are conventional activity measures. Determination of whether or not these measures are associated for reasons other than genetic background is an open question requiring a different experimental design.

\section{REFERENCES}

EsTEs, W. K. Spontaneous recovery from extinction in maze-bright and maze-dull rats. Journal of Comparative Psychology, 1942, 34, 349-351.

Festing, M., \& StaAts, J. Standardized nomenclature for inbred strains of rats. Transplantation, 1973, 16, 221-245.

Fuller, J. L., \& Thompson, W. R. Behavior genetics. New York: Wiley, 1960.

HaRRINGTon, G. M. Genetic-environmental interaction in "intelligence." I: Biometric genetic analysis of maze performance of Rattus Norvegicus. Developmental Psychobiology, 1968, 1, 211-218.

HARRINGTON, G. M. Strain differences among rats initiating explo- ration of differing environments. Psychonomic Science, 1971, 23, 348-349. (a)

HARRINGton, G. M. Strain differences in rotating wheel activity of the rat. Psychonomic Science, 1971, 23, 363-364. (b)

HARRINGTON, G. M. Strain differences in open field behavior of the rat. Psychonomic Science, 1972, 27, 51-53.

HARRINGton, G. M. Strain differences in activity of the rat in a shuttle stabilimeter. Bulletin of the Psychonomic Society, 1979, 13, 149-150. (a)

HARRINGTON, G. M. Strain differences in activity of the rat using a home cage stabilimeter. Bulletin of the Psychonomic Society, 1979, 13, 151-152. (b)

HARRINGTON, G. M. Strain differences in light-contingent barpress behavior of the rat. Bulletin of the Psychonomic Society, 1979, 13, 155-156. (c)

HARRINGton, G. M. Strain differences in open-field behavior of the rat. II. Bulletin of the Psychonomic Society, 1979, 13, 85-86. (d)

HARRINGton, G. M. Strain differences in passive avoidance conditioning in the rat. Bulletin of the Psychonomic Society, 1979, 13, 157-158. (e)

HARRINGTON, G. M. Strain differences in runway learning in the rat. Bulletin of the Psychonomic Society, 1979, 13, 159-160. (f)

HARRINGton, G. M. Strain differences in shuttle avoidance conditioning in the rat. Bulletin of the Psychonomic Society, 1979, 13, 161-162. (g)

HARRINGton, G. M. Strain differences in simple operant barpress acquisition to an auditory stimulus by rats. Bulletin of the Psychonomic Society, 1979, 13, 163-164. (h)

Harrington, G. M., \& Hellwig, L. R. Strain differences in basal metabolism of behaviorally defined rats. Bulletin of the Psychonomic Society, 1979, 13, 165-166. (a)

Harrington, G. M., \& Hellwig, L. R. Strain differences in organ weights of behaviorally defined rats. Bulletin of the Psychonomic Society, 1979, 13, 167-169. (b)

Harrington, G. M., \& Kohler, G. K. Strain differences and sensory reinforcement with shock. Psychonomic Science, 1966, 6, 419-420.

Heron, W. T., \& SKInNer, B. F. Rate of extinction in maze bright and maze dull rats. Psychological Bulletin, 1939, 36, 520.

Heron, W. T., \& Sxinner, B. F. The rate of extinction in maze bright and maze dull rats. Psychological Record, 1940, 4, 11-18.

International Committee on Laboratory Animals. Defining the laboratory animal. Washington, D.C: National Academy of Sciences, 1971.

LOCKARD, R. B. Some effects of maintenance luminance and strain differences upon self-exposure to light by rats. Journal of Comparative and Physiological Psychology, 1962, 55, 1118-1123.

SkInNer, B. F. The abolishment of a discrimination. Proceedings of the National Academy of Sciences, USA, 1933, 19, 825-828.

SkInNer, B. F. The behavior of organisms. New York: AppletonCentury-Crofts, 1938.

(Received for publication January 16, 1979.) 